\title{
Settlement of Indonesian disorientation of democracy: perspective of legal culture
}

\author{
Muhammad Yusrizal Adi Syaputra* and Mirza Nasution \\ Doctoral Program in Law, Graduate School, Universitas Sumatera Utara, Medan, Indonesia
}

\begin{abstract}
The orientation of Indonesian democracy is the establishment of an Indonesian rule of law based on Pancasila. The disorientation of Indonesian Democracy caused the unstable political situation, uncontrolled freedom of press, uneven law enforcement. This situation has resulted in the low quality of democratic implementation in Indonesia compared to ASEAN countries. This research uses a normative juridical method with qualitative. The theory of "law is the spirit of the volk" which pioneered by von Savigny and the theory of legal system by Friedman will be the theoretical analysis in this research. Based on theory law is the spirit of the volk by Savigny, the current Indonesian state administration is not in accordance with the culture and history of the Indonesian nation. The cause of disorientation of democracy in Indonesia, first, the existence of cultural degradation of society. Second, the destruction of the legal and political system. Third, uncontrolled freedom of press. Pancasila as the volkgeist (spirit of the nation) of Indonesia should be the basic of state administration. Based on the legal system theory, the revitalization of Pancasila's values and the legal culture education is the solution to resolve disorientation of Indonesian democracy.
\end{abstract}

\section{Introduction}

Better political, economic, legal, social and cultural change is at the heart of the reform movement of 1998. All the components of the student-driven nation bring democracy to build an open society life and increasingly visible public participation. ${ }^{[1]}$ Post-New Order (era reform) in 1999 marked with the spirit of democratization and uphold human rights (HAM), but also colored euphoria of freedom and spirit of resistance to all things that smell of new order, so impressed irrational and emotiona ${ }^{[2]}$.

The reform movement was born as the answer to the crisis that hit various aspects of life in the political crisis, economy, law, and social crisis which in turn gave birth to the crisis of trust. The demands of the reform movement in 1998 were the transformation of the political system from authoritarian to democratic, the amendment of the 1945 Constitution, the freedom of press, the protection of human rights, the protection of constitutional rights of citizens and the implementation of elections.

\footnotetext{
*Corresponding author: yusrizal.1986@gmail.com
} 
The reform wave of 1998 has ushered Indonesia into three political choices: first, the continuation of the reform movement. Second, the occurrence of the Revolution. Third, the ongoing involution. The choice happens to continue the path of reform.

During the reign of President B.J. Habibie, there was little a change. For the sake of Indonesia's economic recovery, the government continues to cooperate with the International Monetary Fund (IMF), granting freedom to the media, freedom of expression such as the liberalization of political parties, freedom of expression and the annulment of subversive legislation, and issuing human rights law $^{[3]}$. In addition to the transition of political power from the new order to the reform order, it turns out that Indonesia's reforms provide a record of human rights violations. Some brief notes on human rights violations are to include:

First, there is a case that is not yet known who the perpetrators are, although there are indications that the perpetrator has a power of national security. This is evident from the case of Marsinah and the killing of Udin journalists. Secondly, even though the perpetrators are known and allegedly tight is the security apparatus, the perpetrator was never filed by the court. For example, the case of the DPP-PDI office raid on the Diponegoro road, Jakarta on July 27, 1996. Third, the existence of qualifiers certain areas as military operation area (DOM), in Timor-Timor (now Timor Leste), Irian (Papua), and Aceh. This has the potential to encourage the use of violence that leads to human rights violations, since such acts can be qualified as political violence so that the institution must be positioned as a responsible party. Fourth, even though the security authorities acknowledge their involvement in a case, the acknowledgment is deconstructed to merely a person's fault. Or the qualification of errors is denied merely a procedural error, so the punishment being handed down becomes light, a court decision unacceptable to common sense. For example, in the case of the Trisakti student shootings (May, 12th 1998), also in the case of kidnapping numbers of pro-democracy activists during 1997 to 1998 .

The 1999 general election was an important political breakthrough of the President B.J.Habibie government in order to form a new government that gained popular power. The amendment of the 1945 Constitution and the direct presidential and vice-presidential elections also became the agenda, marked by the formation of a National Team of Reform towards the Civil Society to design a political, economic and legal reform program ${ }^{[4]}$. One of the working groups formed is the Law and Legal Reform Group, which is responsible for drafting the proposed amendments to the 1945 Constitution and direct presidential elections. This group produces two things. The main point is to proposed amendments of the 1945 Constitution, and the direct presidential election.

The principle of 1998 reform in Indonesia is the strengthening of the supremacy of civil society in Indonesia. This is triggered by the development that occurred in the international world. Renewal ideas such as freedom of the press, freedom of expression, political freedom, equality and justice enter through communication channels such as mass media, public discourse, and increasingly sophisticated global information technology.

Economic, political, and legal reforms will not produce long-term result if not seen as well as a cultural reform. The reformers should be at the forefront of enlightenment that builds the national awakening. The lack of enlightenment of democracy and human rights and the environment will only make the reformists suffer from myopia which in turn will only promote the short-term interests of the individual, family, class, more than the long-term interests of the whole nation. The lack of a cultural perspective, will only make reforms into temporary phenomena and keratonism will be control back in a period time. The deficient in cultural reform will make corruption, collusion and nepotism as a norm and the reform as an exception at the other side. It could proven as the Indonesian experiences during the Old Order and the New Order ${ }^{[5]}$.

The escalation of complexity due to modernization brings the universal problems experienced by various societies, especially in Indonesia, namely the issue of social integrity 
and social solidarity amidst the facts of pluralism and relativism of values. Democracy in Indonesia, which became the spirit of the goal of the 1998 reform process, becomes invaluable if its structure is not based on the legal, social, economic, and political reform context and especially the morality of the Indonesian people.

In fact, currently Indonesia has experienced degradation of the system in the implementation of life in society, nation and state. The available law is increasingly confusing and fraudulent in its formation in the House of Representatives. Political parties no longer carry out their role as agents of social change of society, but rather to the means of achieving political power alone. The state economy is controlled by the owners of capital and the dependence of foreign loans. There is a disorientation of democracy that the 1998 reform movement aspires to, especially in the press or media. This is evident from the spirit of media coverage that is no longer based on the news to build and increase social awareness of Indonesian society or more precisely said that the press/media increasingly wild and can not be controlled by the government in providing information to the public. Indonesian society culture in the use of information technology increasingly unlimited change the behavior of society becomes worse because of easy to receive information that not yet known truth.

\section{Formulation of the Problem}

The problem to be answered in this research is; What is the form of disorientation of democracy in politics, law, government and media in Indonesia?

\section{Research Method}

This is a legal research that uses normative legal research methods. Normative legal research is a study that examines the study of documents, which uses various secondary data such as legislation, court decisions, legal theory, and can be the opinions of scholars. This research will uses qualitative analysis by explaining the existing data and theory that related to answer the problems.

\section{Literature Review}

The Hegel concept of the "universal idea" (universal spirit) has disturbed the romantichistorical German writers. To them, there is no such thing as a "universal soul". There is only "the soul of the nation". The universal soul can not negate the soul of the nation at the local level. The soul of the nation is an independent unit and is not subject to the universal value unit as Hegel states. The privilege of this nation's soul was initiated by Gustav Hugo (1764$1861)$ and fully developed by Frederick Carl Von Savigny (1779-1861). ${ }^{[6]}$

According to Savigny that to the organic relationship between the law and the character of a nation. Law is a reflection of Volkgeist. Savigny stated that the law is embedded in culture. The law is understood as the soul of the nation (Volksgeist), which is closely related to the common language ${ }^{[7]}$.

Savigny's thesis states that the law from the beginning of history has attached national features. As with language, customs, and constitutions all of which are peculiar to the people. The law does not arise by chance but is born from the inner consciousness of the people. Seen as a form of cultural tradition, history and express a sense of cultural unity of a nation. According to Savigny there is no law that transcends time and space. Laws are always contextual and historical.

According to Savigny, the development of law and society through three stages. The first is development through the formation of political elements that are legal principles not found 
in the law, but are part of the belief and spirit of the society (volksglauben). The second is to transform political elements into legal technical elements of juristic skill. In this period the community is at the top of a legal culture and is a good time to codify the law. The third is marked by the decline in the existence of a society/nation. At this stage the law is no longer the breath and pulse of the life of a society, but only becomes an asset and hegemony of jurists. If this situation is present, then the nature of the society has lost its identity and by itself the law no longer has a meaningful role ${ }^{[8]}$.

Savigny's view was then reinforced by his disciple G. Puchta. Puchta formulated that the law grows together with growth, and becomes strong with the strength of the people, and in the end it dies when the nation loses its nationality. ${ }^{[9]}$

The state organization which based on law and politics always gives the color that law and politics are two inseparable parts. The state organization is based on law, while politics is the driving force for the country to work to meet the needs of its people. Starting from the economic, social, administrative, service, legal and other needs. The implementation of the state in the form of a democratic government as it happens in Indonesia. Democracy is the choice of the will of the Indonesian people, adapted to the circumstances of Indonesian society. Adjustment of the implementation of democracy in Indonesia with the legal system is a step to become Indonesia becomes a strong legal state and make as a prosperous country.

The occurrence of synchronization to all areas of state administration is not limited to the mismatch between the law alone. But it relates to the whole sub-system of a legal system applicable in Indonesia. The Indonesian legal system is a sequence of parts of the overall forming of a complex national legal system and an interplay of entities.

The pattern of democratic implementation based on the law in Indonesia can not be separated from the implementation of state law. the implementation of positive law in Indonesia is based on the legal system adopted by Indonesia. Talking about the legal system can not be separated from a view of Lawrence M Friedman. Friedman is a legal thinker who argues that a legal system within a country can work well and must meet its elements entirely.

Friedman states that the three elements of the legal system consist of ${ }^{[10]}$ :

1. Substance rule of the law, inside it covers all the rules both written and unwritten, both material law and formal law.

2. The legal structure, encompassing legal institutions, legal apparatus and law enforcement system. The legal structure is closely related to the judicial system implemented by law enforcement officers, in the criminal justice system, law enforcement applications carried out by investigators, prosecutors, judges and advocates.

3. Legal culture, is the emphasis of the culture in general, habits, opinions, ways of acting and thinking, which direct social forces in society.

The placement of Friedman's view of the legal system against Indonesia then, in principle, the Indonesian legal system can also be categorized as comprising three elements of the friedman's legal system.For the substance of the law, the implementation of government is based on the constitution and legislation available in various forms of written norms, and unwritten norms.

The legal structure of the legal system in Indonesia is also fulfilled because in Indonesia there are legislative bodies, legislative bodies, executive and judicial bodies (judiciary) institutions or legal institutions such as courts, prosecutors and others. For legal culture that seen from the characteristics of Indonesian society in implementing law and government.

The legal system of Indonesia is an open system, meaning among the elements that make up the mutual legal system. In addition, the Indonesian legal system receives influences from the environment, both in the form of information and in the pressure groups of the political elites who suppress and impose the will on bodies given the legislative and executive councils or the judiciary. ${ }^{[11]}$ 
The influence of the legal system in the implementation of government democracy in Indonesia is seen in all elements of Indonesian legal system. Indonesian democracy is the embodiment or implementation of the legal system within the framework of government. Democracy is a typical government that puts the will of the people and is based on the constitution. Democracy without constitution will be brutal and create chaos.

\section{Result and Discussion}

The rule of law is a very important tool in the administration of a democratic government. The development of Indonesia's increasingly dynamic government with a wide spectrum. The paradigm shift in the implementation of a centralized centralized government of Indonesia into decentralization also requires legal prerequisites in accordance with the paradigm. The demands of the 1998 reforms to make the government of Indonesia a democratic government have come into being with the development of a governance system. The spaces of government are filled with democratic colors, including law, politics, economy, social and others.

Today the democratic system is considered the best system among all the bad. That's why $90-95 \%$ of countries in the world claim to adhere to democracy. Although in practice its application depends on the interpretation of each country and the rulers of the so-called democratic country. ${ }^{[12]}$ one of the most commonly expressed weaknesses is that democratic systems rely too much on majority voices in accordance with the doctrine of "one man one vote". The principle of democracy is according to Jimlly Asshiddiqie synonymous with the capitalist system in the business world that prioritizes the principle of "one share one vote". Who has the most shares is the one who determines the decision. Though the majority of votes do not necessarily reflect the truth and justice.

To compensate for the inherent weakness of the democratic system, the decision-making process in the dynamics of state power must be balanced with the principle of justice, nomocracy (rule of law). True democracy is a democracy based on law (certainty), order, fair and equality of the parties. According to Asshiddiqie that the idea of democracy and nomocracy must be aligned and in line to be said as a democratic state as well as a state law.

Modern democracy in line with the rule of law has the following basic criteria: first, the freedom that is expressed in opinion and the association set forth in the constitution. Second, public participation in politics. Third, the existence of commonality before the law and government on every citizen. Fourth, protection of human rights.

Historically, since the early movements of Indonesian independence, the leaders and predecessors of the Indonesian nation such as H.O.S.Tjokrominoto, Soekarno and Mohammad Hatta have emphasized the importance of popular sovereignty. Among others, it is because of the favor and the nature of that vocation, Sarekat Islam (SI) until the first bellah of this century appeared as the only symbol of resistance against the colonists. When later born various political parties as a container of the struggle to achieve independence, the sovereignty of the people is always included as ideals that will be realized if Indonesia gained independence. The spirit of upholding the sovereignty of the people that causes the founders of the Indonesian nation prefer the form of the state of the Republic rather than the form of a royal state.

People's sovereignty which is the basis of the implementation of the system of governance in Indonesia is set in the 1945 Constitution. It is a derivation of Pancasila as the foundation of the Republic of Indonesia. The five precepts of Pancasila are Belief in the One God; Just and civilized humanity; The unity of Indonesia; Democracy led by the wisdom of thoughts deliberations of representation and Social Justice for all the people of Indonesia 


\subsection{Politics}

During the New Order period, the growth of political parties was limited as a result of the ongoing instability of parliamentary democracy in the early 1950s. In this case, the existence of political parties is more regarded as a problem. So the space is limited and its existence is only intended as a tool of the legitimacy of the then ruling regime of President Soeharto ${ }^{[13]}$. At that time the political party could not carry out its role and function, other than just as a means of mass mobilization in elections and a mere power channel.

2004 was the first year of the presidential and vice presidential elections in Indonesia directly by the people. People are given the freedom to choose a leader, and it is regulated in the 1945 Constitution. Until now three times the president and vice president of Indonesia directly elected by the people. The political process in the presidential and vice-presidential elections in Indonesia keeps the political party into a vehicle for the implementation of elections. Candidates for president and vice president are proposed by political parties either themselves or any combination of political parties with the provisions regulated by law. Political parties remain the main actors in the political system in Indonesia. Political parties become channels to occupy candidates for government authority either in the center or in the region. Slightly different from the presidential and vice-presidential elections, regional heads as leaders in the region are also directly elected by the people to be proposed by political parties or independently.

According to Huntington, stability, party hooliganism and party system will be highly dependent on the degree of institutionalization and participation. Broad participation coupled with a low degree of institutionalization of political parties will result in anomic politics and violence. Participation without an organization will degenerate into a mass movement, while organizations that do not engage in participation tend to lead to personal clicks. ${ }^{[14]}$

Political parties have a special place in the political system of Indonesia. But the political part has not contributed the most in the effort to increase and significant change of decision making in government. Political parties have lost the direction and purpose to give and accommodate the interests of society, so that the current political party becomes a place of transaction interests of the political elite who dominate power in Indonesia. Political parties turn into transactional, party cadres no longer really come from people who are fully part of political parties. Not a few senior party officials who served previously are members of other political parties, then move to another party, when he no longer get the original position of the party.

Based on these conditions, it is difficult to expect the political party will carry out its function maximally as an institution for the formulation of political ideals, articulating political interests, providing enlightenment, and conducting constructive public mobilization and conducting guidance and political recruitment. The plurality of post-reform political parties does not address the political demands of society as a whole. The large number of political parties is not proportional to the ability of political parties to aggress and articulate public interest as well as pluralistic. ${ }^{[15]}$

\subsection{Law}

In the field of law became a sharp spot in the 1998 reformation. The demand for legal reform is the absolute desire of the reform movement. As a result, all areas of law are subject to change both in the process of formation and implementation up to their supervision. In this research. Issues of law enforcement and formation into spaces that must be filled with change. Legal establishment (legislation) by House of Representative and President is explicitly regulated by the 1945 Constitution. The People's Representative Council together with the President has a legislative function that is the function to formulate law. 
Based on Friedman's legal system theory that the implementation of a legal system influenced by legal structuring components, legal substance and legal culture in the Indonesian context becomes something that can be seen clearly;

The presence of legal institutions as part of the implementation of the legal system such as the legal establishment (the People's Representative Council with the President), and the implementing institutions of law such as the judiciary, the Police Service, the Prosecution Service, the Penitentiary, the Corruption Eradication Commission (KPK) affect how the law works within the Indonesian legal system.

Corruption is a form of abuse of power for personal, group or group interests. Corruption today is a global problem for every country including Indonesia. Eradication of corruption if guided by Friedman's legal system theory then all components of the legal system must be considered its role. From the start of the legal structure, its substance and its legal culture must be implemented well and in accordance with their respective functions. Improvements in the legal structure by optimizing the performance of legal institutions, eliminating rivalry in the handling of corruption cases between the police, prosecutors and the commission to eradicate corruption is one way to combat corruption in Indonesia. Building cooperation among law enforcement agencies and mutually shaping commitment responsibilities is the first step in war against corruption.

Culturally, the people of Indonesia have a soul that is embedded in the nation moral values and ethics that can be used as guidance of life in society, nation and state. The social character of Indonesian society with the spirit of gotong royong must be returned to the real purpose so as not to get that character or nature that becomes the basis of corruption, collusion and nepotism.

The appreciation of Pancasila values as Volksgeis (soul of the nation) to all levels of society is a form of reform of the culture of Indonesian society. Pancasila is supposed to be a life guide and guidance in running the law and government of Indonesia.Pancasila as the spirit of nationalism.

\subsection{Government}

Democratic principles embodied in legislation are reflected in the institutional structures and mechanisms of state and government to ensure the establishment of the legal system and the functioning of democracy. From an institutional perspective, democracy is usually organized through a system of separation of powers or distribution of powers. Separation of powers tends to be horizontal in the sense that separation of powers into functions reflected in checks and balances of state institutions. In a vertical sense, the power of state administration is passed down to state institutions under the constitution ${ }^{[16]}$

The implementation of presidential government system in Indonesia is regulated in Article 4 of the 1945 Constitution. The mechanism of election of the head of government in the presidential system is through direct election by the people, while the head of government in the parliamentary system is not through direct election by the people, but through mechanism in parliament so that the basis of legitimation politics comes from parliament. Consequently, the head of government (prime minister) in the parliamentary system is accountable to parliament. ${ }^{[17]}$ The basis of presidential legitimacy in the presidential system is politically derived from the people. The basis of legitimacy is obtained by the president through direct electoral mechanism by the people with a fixed term of office. Therefore, politically the president is responsible to the people not to the parliament. The consequence is a permanent presidential term, president and vice president can not be dismissed amid his term of office for political reasons.

The implementation of Indonesian presidential system in multiparty system can be seen that the application of presidential system with multiparty is not suitable. Currently, 
Indonesia is implementing an extreme multiparty system, should the implementation of a presidential system be implemented with a limited multiparty system. Presidentialism prevailing today needs to be refined in order to produce a strong, stable and effective system of government on the one hand, and to avoid authoritarianism on the other. The effectiveness of presidential government can, among other things, be achieved through the simplification of party system and political grouping in parliament, while authoritarianism can be avoided through the institutionalization of oppositional forces.

\subsection{Media}

In the context of democracy, mass media or the press is expected to become an institution that contributes to strengthening democracy through the coverage of political life that can educate public readers to understand public issues so as to provide quality political support. Therefore, efforts at the institutional level have been made through the creation of laws that create a democratic media system, but unfortunately there have been no serious attempts to reform the media workers. ${ }^{[18]}$

Habermas emphasized the importance of the availability of "undistorted communications" channels, which are the primary means of liberation for participation in the public sphere, the place where individuals can interact with society at large. It is undeniable that the provision of objective and partial channels will help minorities to engage more actively. In other words, "undistorted communication" will empower minority groups in demanding position; also demand equal rights. ${ }^{[19]}$

The reality of the existence of the press as a pillar of democracy in Indonesia today no longer plays its role well. Some electronic media or print media that no longer be a tool of people's voice, but has become the owner of political elites. There are several private television stations in Indonesia where the owners or high-ranking officials are plunged into practical politics, and use the television media as a tool of personal political campaigns, groups or groups. Media press in Indonesia, currently no longer stands on independence and neutrality in the news. The media has changed its function, becoming a tool of particular elite political control or ruler in order to provide information to the public.

But as a comparison in the United Kingdom, starting in 2001 the type of digital media, which uses internet, mobile cellular, and special television (digital) has been used for public service, as well as commercial. Sir Christopher Bland, head of the BBC, in 2005 the digital media system was used extensively to complement the conventional broadcast role both for television and radio. In 2001 the BBC in his country began to enjoy the digital television era with BBC Three, BBC Four, and BBC Children Channel. As for radio, digital systems are used for BBC Network X, Network Y, Network Z, BBC Sport (BBC Radio 4 and 5), and BBC Asean Network. While outside the BBC who already use the digital system is ITV, Channel 4, Chanel 5, and S4C. But for Indonesia, this type of media is still very limited, because it is only an alternative media. ${ }^{[20]}$

Media commercialization in Indonesia and the suburings of mass media business in Indonesia make new land the political means of power. Weak legal substance that regulates media/press in Indonesia to make the media or press can easily inform the news that is not necessarily the truth.

\section{Conclusions}

\subsection{Summary}


Implementation of democracy in Indonesia in the field of politics, law, government, and the field of a press in Indonesia has not yet realized the criteria in accordance with the ideals of democracy of Indonesian society. The implementation of democracy in politics, law, government, and Press does not work well. Political parties have not implemented their roles maximally, law enforcement is not fair, there are government policies that do not side with the people, and freedom of the press that violates the law and ethics.

\subsection{Recommendations}

Firstly, in the political field is to carry out the function of political parties as a pillar of democracy and instill political behavior or culture in the political elite and society in accordance with the values of Pancasila.

Secondly, In the field of law, it is recommended to revitalize the process of formation, development and law enforcement in Indonesia. The formation of law in accordance with the values of Pancasila and the interests of the people of Indonesia with the standardization of the process of formation will result in good, sustainable, equitable, fair and beneficial law for all Indonesians. Legal development is done by establishing a centralized legal institution in order to avoid disorder, miscommunication in carrying out the responsibility of developing the national law. Law enforcement must be resolved through procedural rules and implemented by competent legal institutions. The existence of synergy between law enforcement agencies such as Police, Attorney, Corruption Eradication Commission, and Court and Correctional Institution is the effort to restore the democratic orientation of national law.

Thirdly, in the field of government, it is suggested to the Government of Indonesia to realize policies that prosper the people of Indonesia.

Fourthly, in the press field, it is advisable to limit press freedom to law and ethics, maintain media neutrality by separating the political interests of media owners with journalistic professionalism.

\section{References}

1. F. Hamzah, Demokrasi transisi korupsi : orkestra pemberantasan korupsi sistemik, p. 2 (Yayasan FAHAM Indonesia, Jakarta, 2012)

2. Wahyuno, S. Arinando, dan N. Triyanti (Eds.), Menggugat superiorisasi mahkamah konstitusi dalam menyelesaikan sengketa PEMILU, memahami hukum: dari konstruksi sampai implementasi, p. 254 (Rajawali Pers, Jakarta, 2009)

3. A. Priyadi, A.E. Priyono, dan U. Hamid (Eds.), Reformasi di mata keluarga korban pelanggaran HAM, merancang arah baru demokrasi : Indonesia pasca reformasi, p. 9 (Kepustakaan Populer Gramedia, Jakarta, 2014)

4. V.S. Subekti, Menyusun konstitusi transisi: pergulatan kepentingan dan pemikiran dalam proses perubahan UUD 1945, p. 63 (PT. RajaGrafindo Persada, Jakarta, 2008)

5. A.A. Nugroho, Rakyatisme : dan esai-esai lain, p. 152-153 (Kompas, Jakarta, 2017)

6. B. L.Tanya, Y. N. Simanjuntak, M.Y. Hage, Teori hukum : strategi tertib manusia lintas ruang dan generasi, Cetakan III, p. 103 (Genta Publishing, Yogyakarta, 2010)

7. R. Cotterrell, Law, culture and society : legal ideas in the mirror of social theory, p. 103 (Ashgate Publishing Limited,England, 2006)

8. L. Pospisil, Anthropology of law: a comparative theory, p. 142 (Willey, USA, 1971)

9. Rahardjo, Ilmu hukum, Cetakan VIII,p. 316 (PT. Citra Aditya Bakti, Bandung, 2003) 
10. L. M. Friedman; The legal system; a social scince prespective, p. 12-16 (Russel Sage Foundation, New York, 1975)

11. B. Mustapa, Sistem hukum Indonesia terpadu, p. 74 (PT. Citra Aditya Bakti, Bandung, 2003)

12. J. Asshiddiqie, Pokok-pokok hukum tata negara pasca reformasi, p. 146 (PT. Bhuana Ilmu Populer, Jakarta, 2007)

13. B. Winarno, Sistem politik indonesia era reformasi, Cetakan II,p. 100 (Media Pressindo, Yogyakarta, 2008)

14. S.Huntington, Tertib politik pada masyarakat yang sedang berubah (trans.), p. 476-477 (Rajawali Press, Jakarta, 2004)

15. A. Sanit, Demokrasi, kekuatan masyarakat dan strategi alternatif, in M. MD dan A. MWK, Reformasi politik dan kekuatan masyarakat, p. 130 (LP3ES, Jakarta, 2002)

16. A.M. Fatwa, Potret konstitusi pasca amandemen UUD 1945, p. 11 (Kompas, Jakarta, 2009)

17. H. Y. AR, Presidensialisme setengah hati dari dilemma ke kompromi, p. 17 (PT. Gramedia Pustaka Utama, Jakarta, 2010)

18. I.G.N. Putra, Demokrasi dan Kinerja Pers Indonesia, Jurnal komunikasi, 3, 2, 132 (2004)

19. Centre for Innovation Policy and Governance (CIPG), Tantangan media dan demokrasi: seri 4 rangkaian CREAME (critical research and methodology), http://cipg.or.id/wpcontent/uploads/2015/05/CREAME-4.-Media-Demokrasi-2012.pdf

20. M. Solihat, Diversifikasi media massa dan demokrasi di Indonesia; penguatan peran media massa serta masyarakat dalam mewujudkan demokrasi, Jurnal Ilmu Politik dan Komunikasi, 2;101 (2015) 